\title{
Article \\ Characterization of the Transient Deficiency of PKC Isozyme Levels in Immature Cord Blood T Cells and Its Connection to Anti-Allergic Cytokine Profiles of the Matured Cells
}

\author{
Khalida Perveen 1,2®, Alex Quach 1,2, Michael J. Stark ${ }^{2,3}$ (D) Susan L. Prescott ${ }^{4,5}$, Simon C. Barry ${ }^{2}$, \\ Charles S. Hii ${ }^{1,2}$ and Antonio Ferrante ${ }^{1,2,6, *}$ \\ 1 Department of Immunopathology, SA Pathology at the Women's and Children's Hospital, \\ North Adelaide, SA 5006, Australia; khalida.perveen@adelaide.edu.au (K.P.); \\ Alexander.Quach@sa.gov.au (A.Q.); charles.hii@adelaide.edu.au (C.S.H.) \\ 2 Adelaide School of Medicine and the Robinson Research Institute, University of Adelaide, \\ Adelaide, SA 5005, Australia; Michael.stark@adelaide.edu.au (M.J.S.); simon.barry@adelaide.edu.au (S.C.B.) \\ 3 Department of Neonatal Medicine, Women's and Children's Hospital, North Adelaide, SA 5006, Australia \\ 4 School of Paediatrics and Child Health, University of Western Australia, 35 Stirling Highway, \\ Perth, WA 6009, Australia; Susan.Prescott@telethonkids.org.au \\ 5 The ORIGINS Project, Telethon Kids Institute and Perth Children's Hospital, 15 Hospital Avenue, \\ Nedlands, WA 6009, Australia \\ 6 School of Biological Sciences, University of Adelaide, Adelaide, SA 5005, Australia \\ * Correspondence: Antonio.Ferrante@adelaide.edu.au; Tel.: +61-8-81-617-216
}

Citation: Perveen, K.; Quach, A.; Stark, M.J.; Prescott, S.L.; Barry, S.C.; Hii, C.S.; Ferrante, A.

Characterization of the Transient Deficiency of PKC Isozyme Levels in Immature Cord Blood T Cells and Its Connection to Anti-Allergic Cytokine Profiles of the Matured Cells. Int. J. Mol. Sci. 2021, 22, 12650. https:// doi.org/10.3390/ijms222312650

Academic Editors: Maria Ruzzene and Rafael Pulido

Received: 18 October 2021

Accepted: 17 November 2021

Published: 23 November 2021

Publisher's Note: MDPI stays neutral with regard to jurisdictional claims in published maps and institutional affiliations.

Copyright: () 2021 by the authors. Licensee MDPI, Basel, Switzerland. This article is an open access article distributed under the terms and conditions of the Creative Commons Attribution (CC BY) license (https:// creativecommons.org/licenses/by/ $4.0 /)$.

\begin{abstract}
Cord blood T cells (CBTC) from a proportion of newborns express low/deficient levels of some protein kinase $\mathrm{C}$ (PKC) isozymes, with low levels of PKC , correlating with increased risk of developing allergy and associated decrease in interferon-gamma (IFN- $\gamma$ ) producing $\mathrm{T}$ cells. Interestingly, these lower levels of $\mathrm{PKC} \zeta$ were increased/normalized by supplementing women during pregnancy with n-3 polyunsaturated fatty acids. However, at present, we have little understanding of the transient nature of the deficiency in the neonate and how $\mathrm{PKC} \zeta$ relates to other PKC isozymes and whether their levels influence maturation into IFN- $\gamma$ producing $\mathrm{T}$ cells. There is also no information on PKC $\zeta$ isozyme levels in the $\mathrm{T}$ cell subpopulations, $\mathrm{CD} 4^{+}$and $\mathrm{CD} 8^{+}$cells. These issues were addressed in the present study using a classical culture model of neonatal $\mathrm{T}$ cell maturation, initiated with phytohaemagglutinin (PHA) and recombinant human interleukin-2 (rhIL-2). Of the isozymes evaluated, PKC $\zeta, \beta 2, \delta, \mu, \varepsilon, \theta$ and $\lambda / \iota$ were low in CBTCs. The PKC isozyme deficiencies were also found in the $\mathrm{CD} 4^{+}$and $\mathrm{CD} 8^{+} \mathrm{T}$ cell subset levels of the PKC isozymes correlated between the two subpopulations. Examination of changes in the PKC isozymes in these deficient cells following addition of maturation signals showed a significant increase in expression within the first few hours for PKC $\zeta, \beta 2$ and $\mu$, and $1-2$ days for PKC $\delta, \varepsilon, \theta$ and $\lambda / \iota$. Only CBTC PKC $\zeta$ isozyme levels correlated with cytokine production, with a positive correlation with IFN- $\gamma$, interleukin (IL)-2 and tumour necrosis factor-alpha (TNF), and a negative association with IL-9 and IL-10. The findings reinforce the specificity in using СВTC РКС $\zeta$ levels as a biomarker for risk of allergy development and identify a period in which this can be potentially 'corrected' after birth.
\end{abstract}

Keywords: neonate; cord blood $\mathrm{T}$ cells; $\mathrm{CD} 4^{+}$and $\mathrm{CD} 8^{+} \mathrm{T}$ cells; $\mathrm{T}$ cell maturation; Th1 and Th2/9 subsets; PKC isozymes; PKC ; cytokines; allergy

\section{Introduction}

Protein kinase $\mathrm{C}$ (PKC) is composed of three subfamilies of protein kinases, namely, the classical $(\alpha, \beta 1, \beta 2, \gamma)$, novel $(\delta, \mu, \varepsilon, \theta, \eta)$ and atypical $(\zeta, \iota / \lambda)$ PKC isozymes. The classical isozymes require calcium, diacylglycerol and phospholipids for activation whereas the novel isozymes require only diaylglycerol and phospholipids. Unlike the classical and novel isozymes, the atypical PKC family members, lacking functional C2 and C1 domains, 
require only phospholipids for activation [1,2]. Amongst the atypical PKC isozymes, PKC $\iota / \lambda$ is generally more abundantly expressed and with a wider tissue distribution than PKC $\zeta$ [3]. However, brain, lung and testes have a higher content of PKC $\zeta$ than $P K C \lambda / \iota$. It has been demonstrated that the expression of the atypical PKC isozymes is dysregulated in cancer. Thus, in most cancers, except in melanoma, $\mathrm{PKC} \lambda /\llcorner$ expression is upregulated. Similarly, PKC $\zeta$ expression is also upregulated in many cancers but downregulated in cancer of the brain, lung and testes, the tissues in which its expression is higher than that of $\mathrm{PKC} \lambda / \mathrm{\iota}$ [3].

The atypical PKC isozymes have been reported to be involved in regulating cell polarity, growth of cancer cells, asymmetric cell division and cell-fate determination [3]. PKC $\zeta$ has been reported to promote cell survival via the phosphorylation of Ser311 of RelA, a key member of the NF-kB transcription factor [4]. Our studies in cord blood T cells (CBTCs) also support a prosurvival role of $\mathrm{PKC} \zeta$ as knockdown of the isozyme decreases cell survival [5]. In B cells, $\mathrm{PKC} \zeta$ signalling is important for $\mathrm{B}$ cell activation and survival [6]. In CD8 ${ }^{+} \mathrm{T}$ cells, atypical PKC isozymes have been reported to regulate asymmetric division in fate specification that leads to the development of effector and memory cells. Deletion of either $\mathrm{PKC} \zeta$ or $\mathrm{PKCl} / \lambda$, skews development towards the effector lineage with a resultant deficit of memory cells [7]. Interestingly in mice, $\mathrm{PKC} \zeta$ has been reported to promote the differentiation of murine T cells along the T helper 2 (Th2) lineage as loss of the isozyme results in a severe loss of activation of transcription factors such as GATA3, Stat6 and NFATc1 that are essential for Th2 polarisation [6]. The role of PKC $\zeta$ in Th cell differentiation is clear different between mice and human.

The perinatal period is characterised by an adaptive Th2 cytokine bias, reflecting the immunomodulatory milieu of pregnancy. Thereafter, normal immune maturation depends on effective switching to more mature and regulated Th1 responses. Failure to do so, with the continual propensity for a Th2 functional phenotype, is associated with predisposition for allergic responses. The molecular basis for this continued Th2 propensity, while of fundamental importance, remains ill-defined. Our work has demonstrated that CBTC from babies whose mothers have a family history of allergy express low PKC C [8]. There was a correlation between these levels in immature CBTC and the development of allergic sensitization at the age of 1-2.5 years. It was also evident that low levels of $\mathrm{PKC} \zeta$ in CBTCs correlated with the development and maturation of cells with a propensity to display Th2 cytokine bias [9]. We have also shown that knocking down PKC $\mathrm{P}$ in CBTC was associated with their development towards a Th2 bias [5]. Together, the data suggest that the PKC $\zeta$ level in immature T cells at birth may be a key determinant in allergy development later in life, either as a consequence of modern environmental changes (declining microbial diversity, pro-inflammatory dietary patterns and environmental toxins) or by creating greater vulnerability to their effects.

We have previously demonstrated that supplementation of women during pregnancy with n-3 polyunsaturated fatty acids or fish oil leads to an increase in the levels of PKC $\zeta$ expression in CBTCs expressing low levels of this isozyme. Since these PKC isozyme levels increase/normalise during maturation [10-12] it is important to characterise the period of low expression since this seems to be a determinant for development towards an allergy cytokine pattern $[5,8,10]$. In this concept, it is proposed that the levels of PKC $\zeta$ prior to T cells being engaged by the maturation agents could be critical to their development to cells with a propensity to produce anti-allergy promoting cytokines. Consequently, it is important to identify if a 'time window' of opportunity exists for potential environmental/epigenetic intervention to modify the pre-maturation signalling of the $\mathrm{T}$ cells.

The deficiency in PKC isozymes was also reported for splenic T cells from 1-day old mouse pups which normalized by 28 days [11]. However, at present, we know very little about the kinetics of $\mathrm{PKC} \zeta$ increases during the neonatal period. Identification of this "early critical window" of development may assist in the development of strategies to alter the risk of subsequent sensitization and disease, such as through nutritional supplementation [13] and other environmental strategies. Furthermore, we know even less about the state of 
other PKC isozymes in relation to such $\mathrm{T}$ cell development and kinetics of changes during neonatal $\mathrm{T}$ cell maturation. In addition, previous work did not examine the PKC isozyme levels in the $\mathrm{CD}^{+}$and $\mathrm{CD} 8^{+} \mathrm{T}$ cell subpopulations. Therefore, the aim of the current study was to examine CD4 and CD8 CBTC PKC $\zeta$ levels and whether other PKC isozyme levels influence maturation towards interferon-gamma (IFN- $\gamma$ ) producing $\mathrm{T}$ cells. Furthermore, the transient state of the PKC isozyme deficiency will be defined, following maturation signal activation.

\section{Results}

\subsection{PKC Isozyme Expression in $C B C D 3^{+} T$ Cells}

Experiments were conducted with whole blood assays using anti-CD3 monoclonal antibody to gate on $\mathrm{CD}^{+} \mathrm{T}$ cells and anti-PKC isozyme specific monoclonal antibodies to detect PKC isozymes by intracellular staining and flow cytometry analysis [12]. To ensure consistency between different runs a standard cryopreserved PBMC sample was run concurrently with each assessment and all results were expressed as a percentage of this standard Levey-Jennings plots were made with this standard to ensure that performance complies with Westgard rules for acceptance of the experimental run.

The data presented in Figure 1 show that $\mathrm{CB} C D 3^{+} \mathrm{T}$ cells express low levels of PKC $\beta 2, \delta, \mu, \varepsilon, \theta, \zeta$ and $\lambda / \iota$ but not PKC $\alpha, \beta 1$ and $\eta$ compared to T cells from adults (Figure 1). The results are expressed as both the individual values and mean \pm SD of the indicated number of samples. The top panel shows an example of an individual sample run, by histograms and the gating strategy used is shown in Supplementary Figure S1.

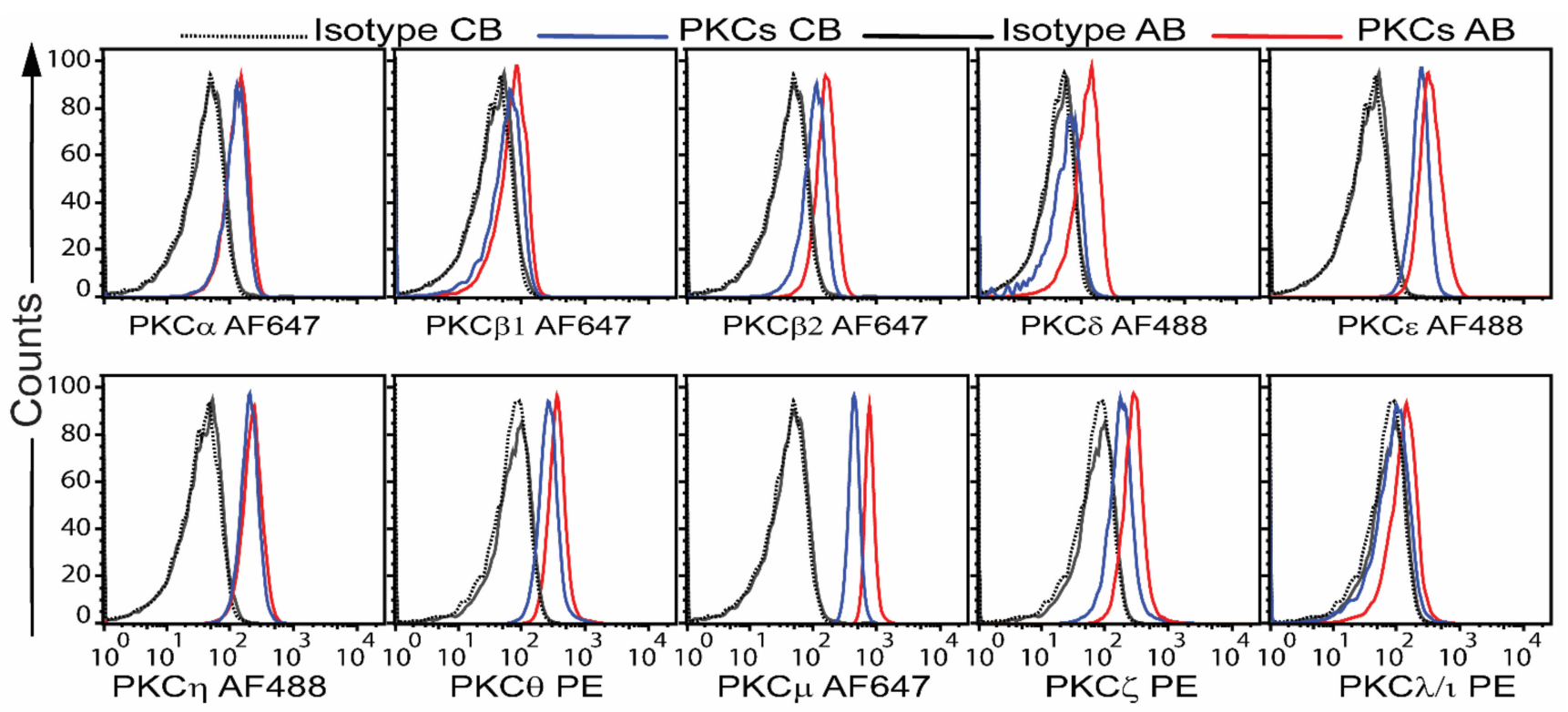

Figure 1. Cont. 


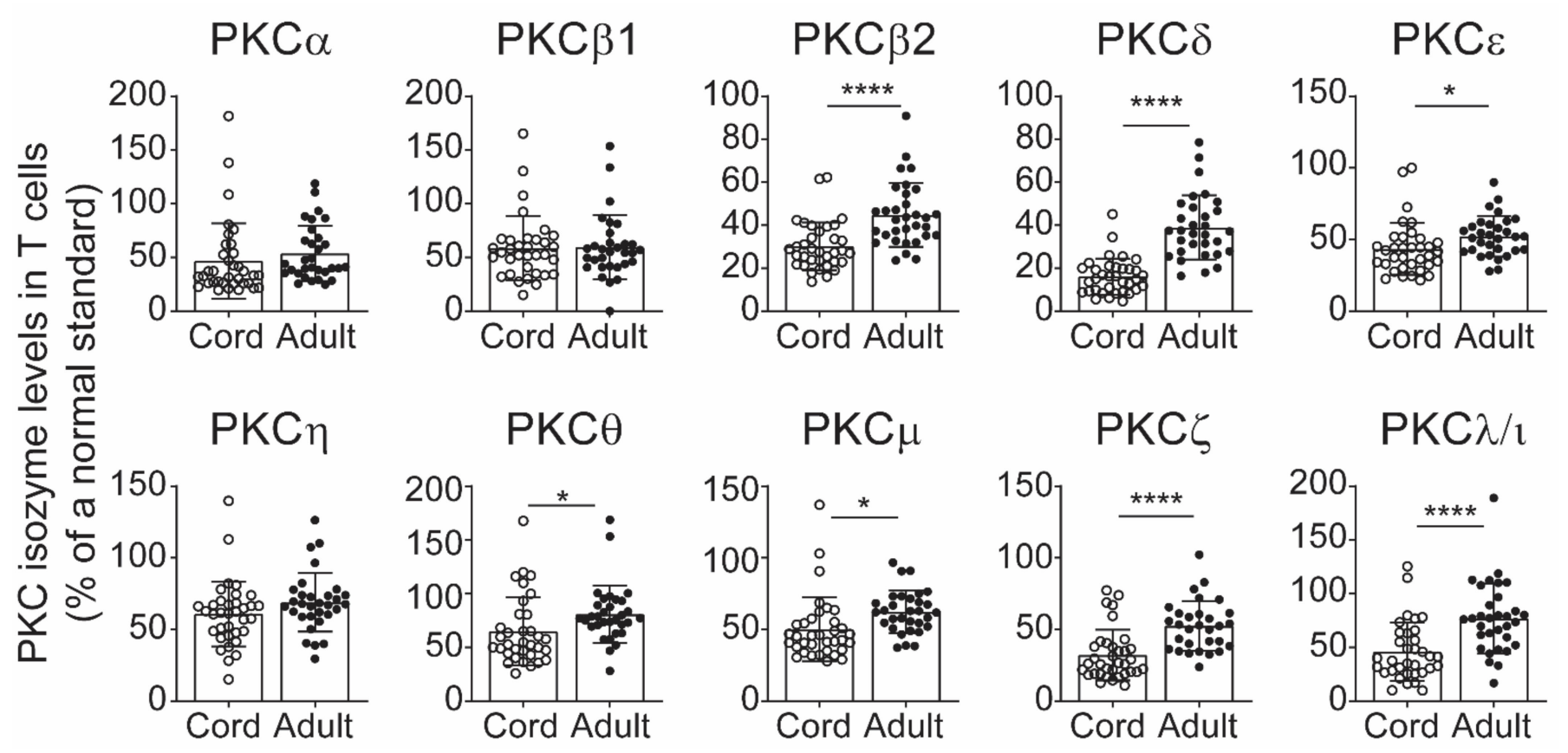

Figure 1. Protein kinase $\mathrm{C}(\mathrm{PKC})$ isozyme expression by $\mathrm{CD}^{+} \mathrm{T}$ cells from cord blood $(\mathrm{CB})$ and adult blood (AB). Whole CB $(n=35)$ and adult blood samples $(n=31)$ were treated with fluorochrome labelled anti-CD3 monoclonal antibody, then cells were permeabilized for intracellular staining using fluorochrome tagged isozyme specific monoclonal antibodies. The cells were then analysed by flow cytometry. Supplementary Figure S1 shows the gating strategies. The median fluorescent intensity (MFI) (after deducting the isotype control values) was obtained and normalized against the standard cryopreserved $\mathrm{T}$ cells, run at the same time, and represented as a \% of this standard. Data are presented as mean $\pm \mathrm{SD}$. ${ }^{*} p<0.05,{ }^{* * * *} p<0.0001$ (Student's $t$-test). The top histogram panels show an example of a cord blood and an adult blood sample.

\subsection{PKC Isozyme Expression in $C B C D 4^{+}$and $C D 8^{+} T$ Cells}

In all previous studies, the levels of PKC isozymes were measured in total $\mathrm{T}$ cells and not the T cell subpopulations. Here the levels in the CD4 and CD8 subsets were examined in the event that we could gain greater specificity by using the subset values. The same blood samples as in Figure 1 were analysed for PKC isozyme expression using the anti-CD3 and anti-CD8 monoclonal antibodies and PKC isozyme specific monoclonal antibodies. The data presented in Figure 2 show that $\mathrm{CB} C D 4^{+}$T cells express low levels of PKC $\beta 2, \delta, \mu$, $\zeta$ and $\lambda / \iota$ but not $\mathrm{PKC} \alpha, \beta 1, \varepsilon, \eta$ and $\theta$ compared to $\mathrm{CD} 4^{+} \mathrm{T}$ cells from adults. Examination in the $\mathrm{CD}^{+} \mathrm{T}$ cell subset showed that $\mathrm{PKC} \beta 2, \delta, \mu, \zeta, \varepsilon, \theta$ and $\lambda / \iota$ were low (Figure 2). This most likely accounts for the same isozymes being low in the total $\mathrm{T}$ cells. However, the data presented in Figure 3 show that there is a highly significant correlation in the PKC isozyme levels between the CD4 and CD8 subpopulations, indicating that the total $\mathrm{T}$ cell PKC isozyme levels are representative of both the $\mathrm{CD} 4^{+}$and $\mathrm{CD} 8^{+} \mathrm{T}$ cells. 

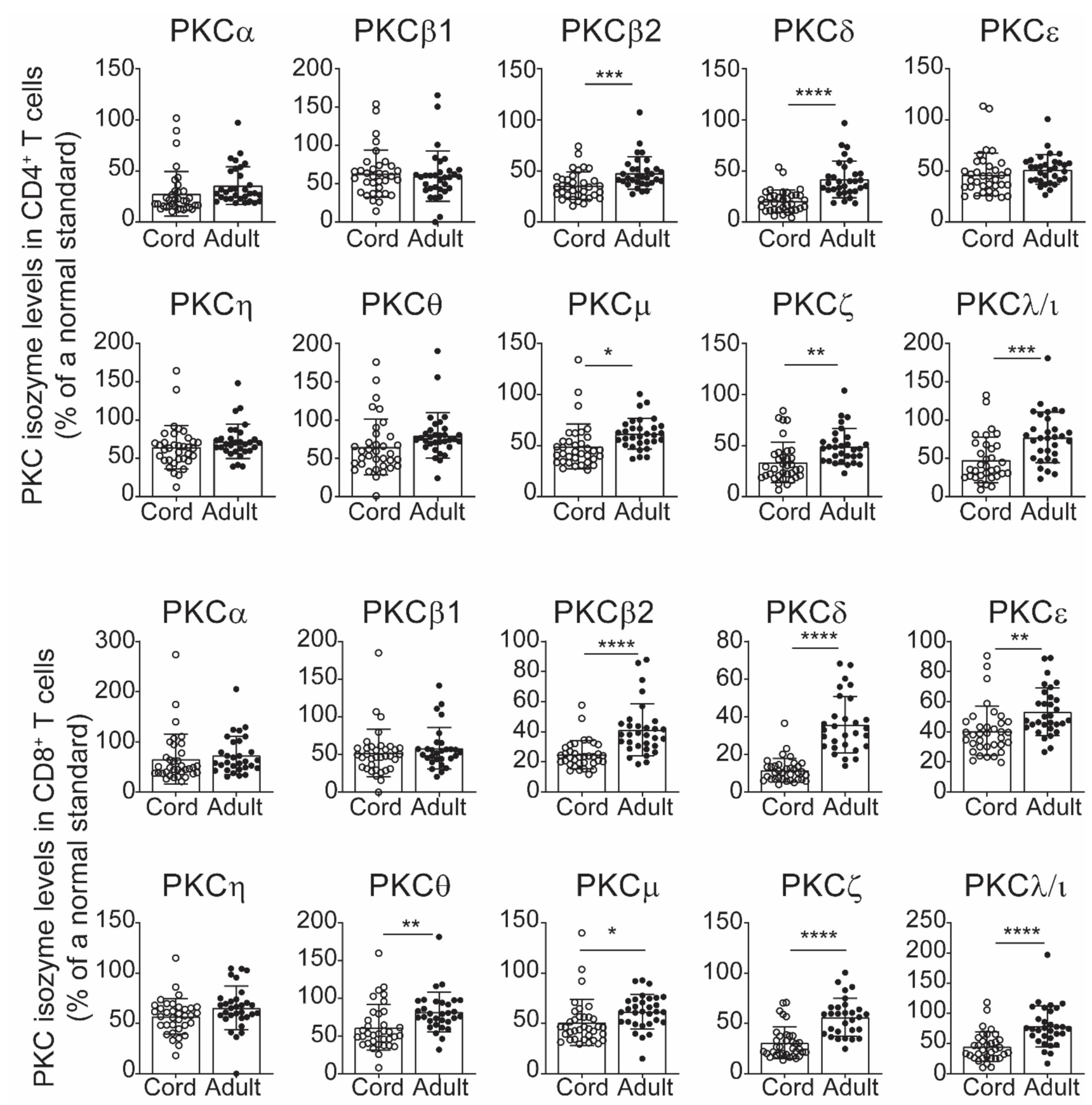

Figure 2. PKC isozyme expression in $\mathrm{CD}^{+} / \mathrm{CD}^{+} \mathrm{T}$ cells from $\mathrm{CB}$ and $\mathrm{AB}$. Whole blood from cord $(n=35)$ and adult $(n=31)$ were treated with fluorochrome labelled anti-CD3 and anti-CD8 monoclonal antibodies and then with fluorochrome tagged isozyme specific monoclonal antibodies for intracellular PKC isozyme detection. Data are expressed as per Figure 1 legend and presented as mean $\pm \mathrm{SD}$. ${ }^{*} p<0.05,{ }^{* *} p<0.01,{ }^{* * *} p<0.001,{ }^{* * * *} p<0.0001$ (Student's $t$-test). 
$\mathrm{PKC} \alpha$

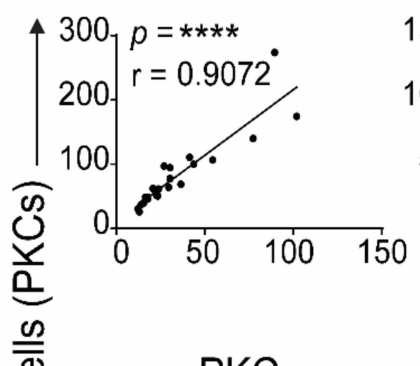

PKC $\beta 1$

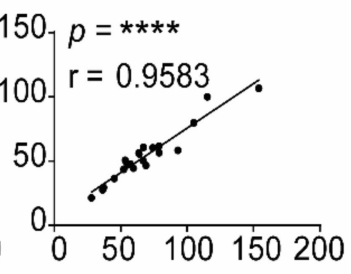

PKC $\beta 2$

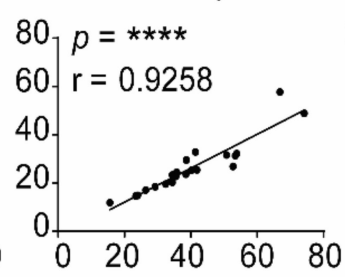

PKC $\theta$

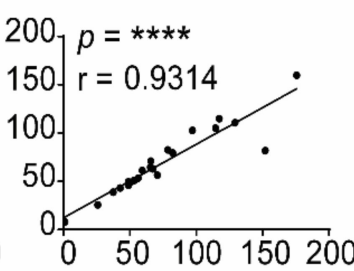

PKC $\delta$
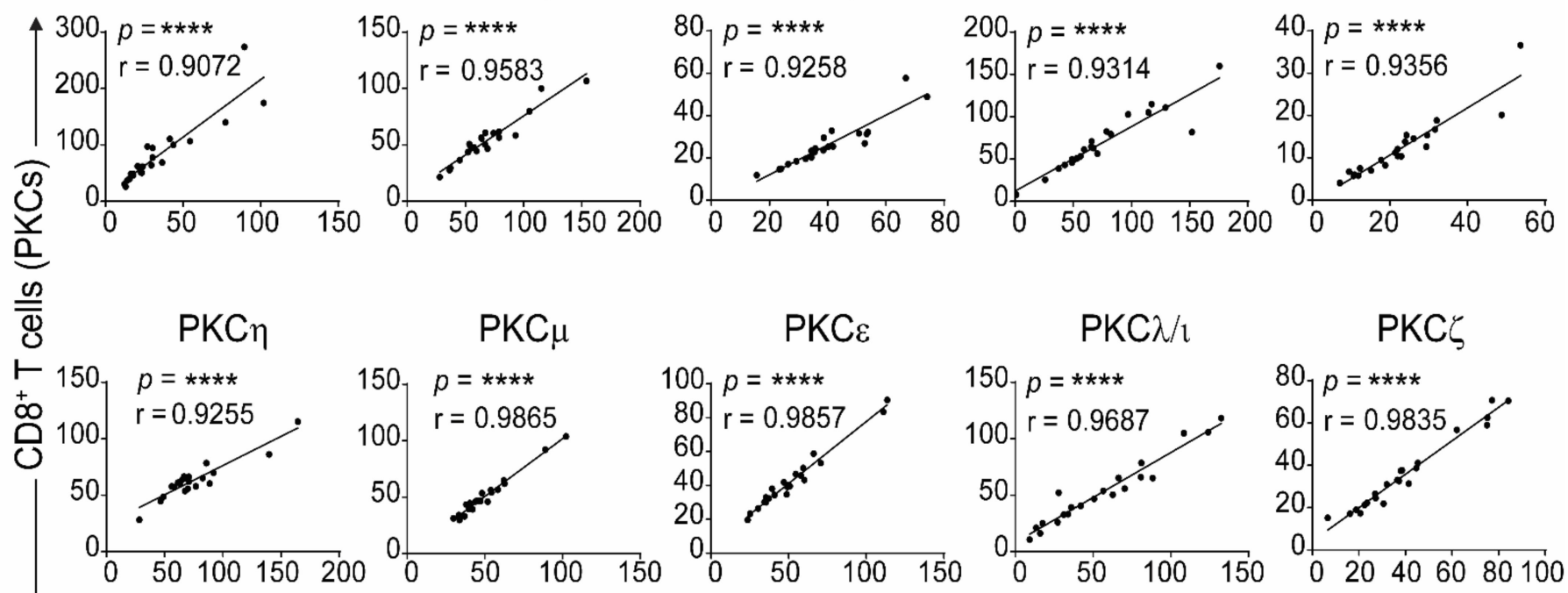

CD4 ${ }^{+} \mathrm{T}$ cells (PKCs)

Figure 3. Correlation of levels of PKC isozyme expression between $\mathrm{CD}^{+}$and $\mathrm{CD} 8^{+} \mathrm{CBTC}$. Data from Figure 2 were subjected to correlation analysis to deduce the relationship of PKC isozyme expression (MFI) between CD4 ${ }^{+}$and CD8 ${ }^{+}$ T cells. ${ }^{* * * *} p<0.0001$. Correlations were performed using the two-tailed Pearson correlation.

\subsection{Transient Nature of the PKC Isozyme Deficiencies in CBTC during Maturation}

In order to determine this window, the changes in the levels of each of the PKC isozymes were determined in an in vitro culture model of $\mathrm{CB}$ mononuclear cells (CBMCs) treated with phytohaemagglutinin (PHA). CB samples in which the T cell PKC isozyme levels were less than the 5th percentile [14] were used. In these cultures, recombinant human interleukin-2 (rhIL-2) was added on the 3rd day after initiating the culture to ensure cell survival during maturation. At the times indicated in Figure 4, the cells were harvested and examined for levels of PKC isozymes by flow cytometry. The data presented in Figure 4 show that T cell PKC isozyme expression increased to within the 5th and 95th percentiles [12] of adult levels by day 7. As the levels were normalized (seen after maturation) within $24 \mathrm{~h}$ of culture for some of the isozymes, we attempted to identify the levels of PKC isozymes prior to this time. The levels of PKC $\zeta$ and $\mu$ in the T cells had normalised by $2.5 \mathrm{~h}$ (Figure 4), while other PKC isozymes took at least $24 \mathrm{~h}$ to show a significant increase (Figure 4). It is noted that this was also the case when examining the $\mathrm{CD}^{+}$and $\mathrm{C} 8^{+} \mathrm{T}$ cell subsets (Figures 5 and 6 ). The data identify a period during which levels of the deficient PKC isozymes are increased to within the normal adult range. 


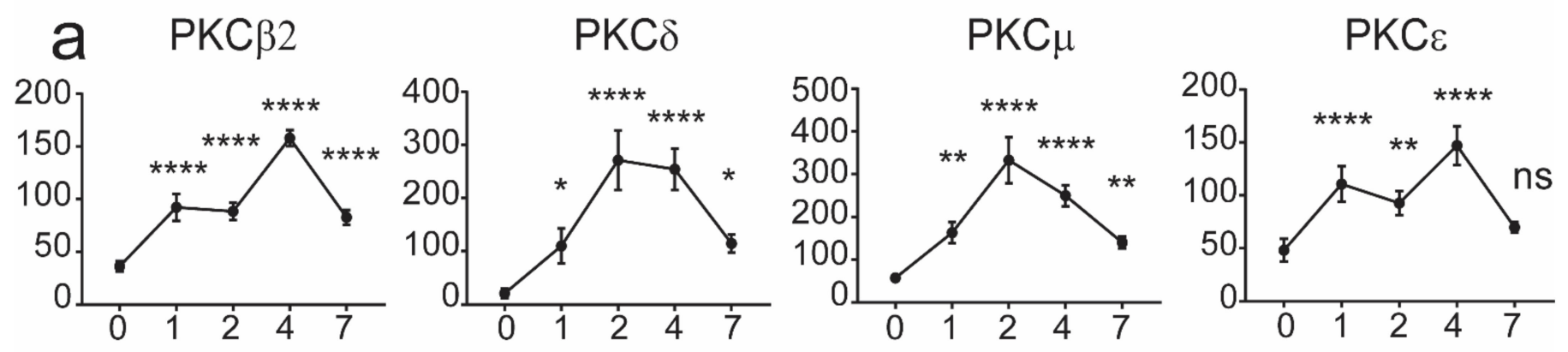

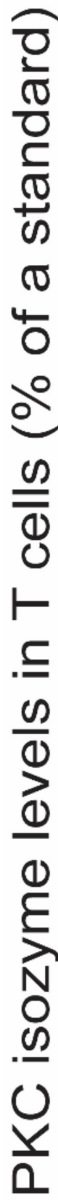
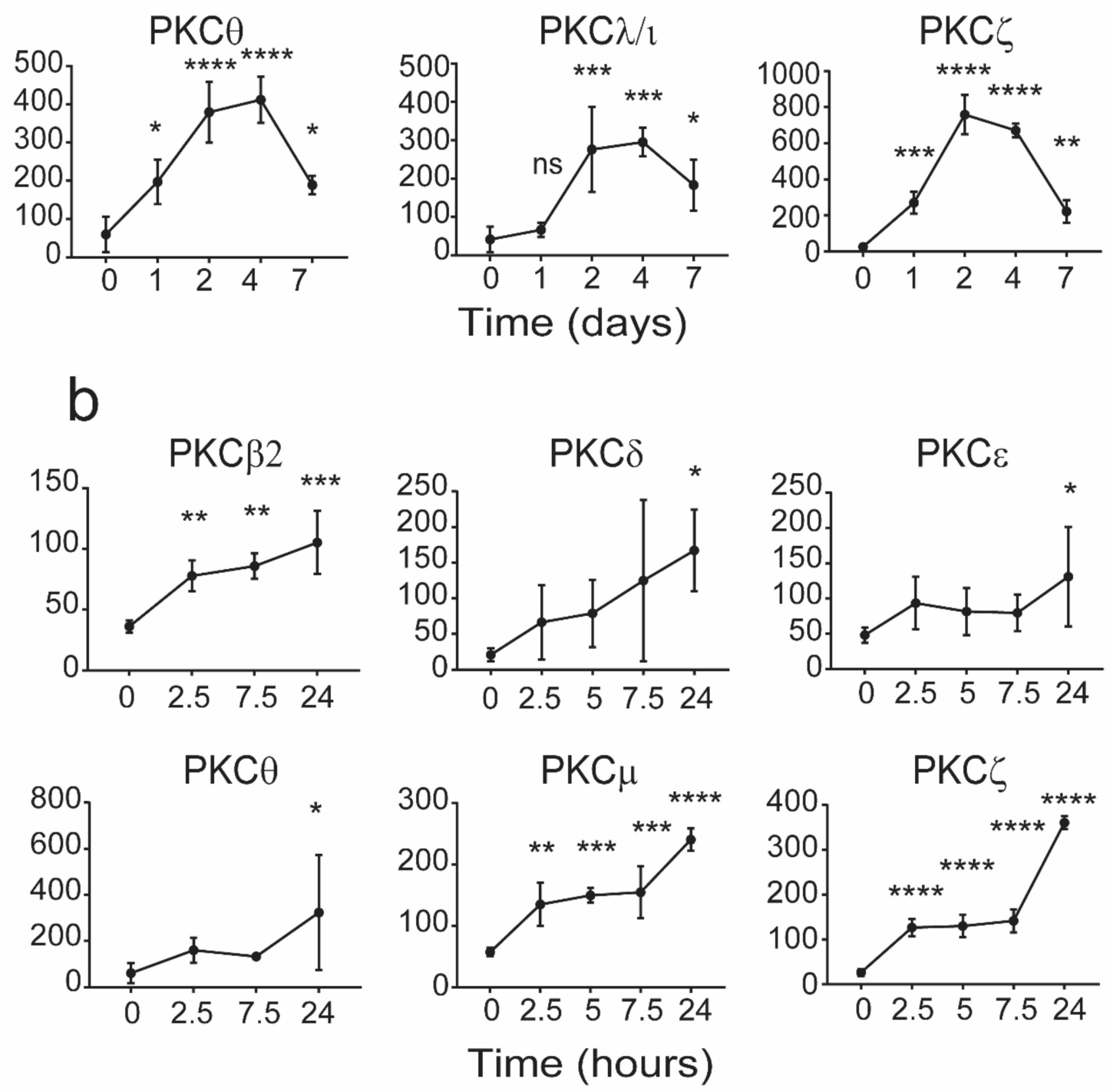

Figure 4. Changes in levels of $\mathrm{CB} C D 3^{+} \mathrm{T}$ cell PKC isozyme levels during 7-day maturation in culture. CBMCs containing T cells expressing low PKC isozymes levels were cultured in the presence of phytohaemagglutinin (PHA) $(2 \mu \mathrm{g} / \mathrm{mL}) \mathrm{and}$ rhIL-2 $(10 \mathrm{ng} / \mathrm{mL})$ and then the levels of PKC isozymes were determined over seven days by flow cytometry (a). For those isozymes which achieved significance at 1 day, the levels were examined prior to $24 \mathrm{~h}$ culture period (b). The MFI for the PKCs is expressed as a $\%$ of the control standard and as mean \pm SD ( $n=4$ each with cells from a different individual). ${ }^{*} p<0.05,{ }^{* *} p<0.01,{ }^{* * *} p<0.001,{ }^{* * * *} p<0.0001$ compared to day-0. ns: not significant. One-way ANOVA with post hoc Tukey's multiple comparisons test. 


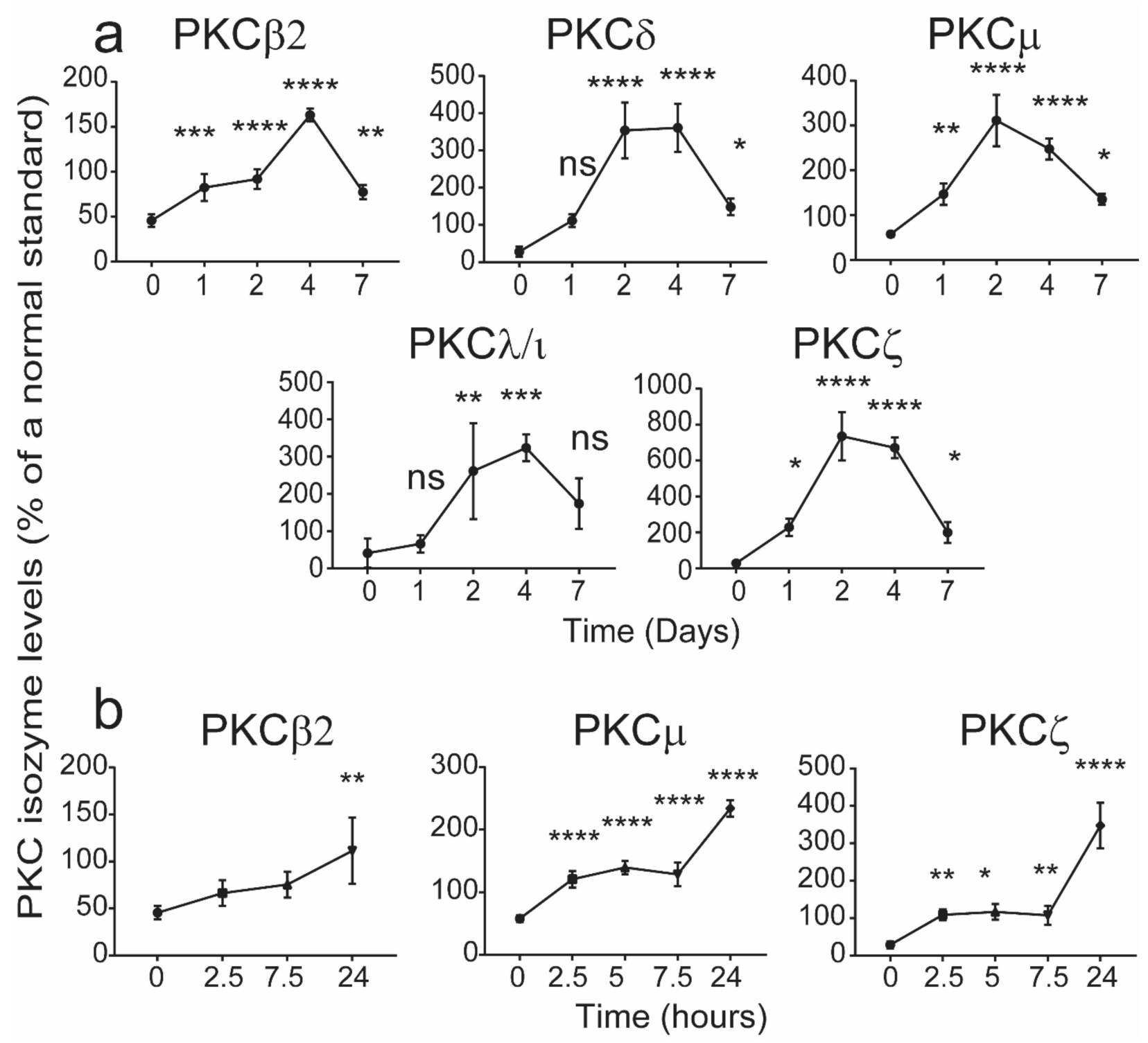

Figure 5. Changes in levels of CD4 ${ }^{+}$CBTC PKC isozymes levels during 7-day maturation. CBMCs with low PKC isozyme expressing PKC isozymes CD4 ${ }^{+}$T cells were cultured in the presence of PHA ( $\left.2 \mu \mathrm{g} / \mathrm{mL}\right)$ and rhIL-2 (10 ng/mL) for 7 days. The levels of PKC isozymes were determined during this culture period (a). For those isotypes which achieved significance at 1 day the levels were re-examined prior to $24 \mathrm{~h}$ culture period (b), by flow cytometry. The MFI for the PKCs is expressed as a $\%$ of the control standard and as mean $\pm \operatorname{SD}\left(n=4\right.$ each with cells from a different individual). ${ }^{*} p<0.05,{ }^{* *} p<0.01$, ${ }^{* * *} p<0.001,{ }^{* * * *} p<0.0001$ compared to day 0 . ns: not significant. One-way ANOVA with post hoc Tukey's multiple comparisons test. 


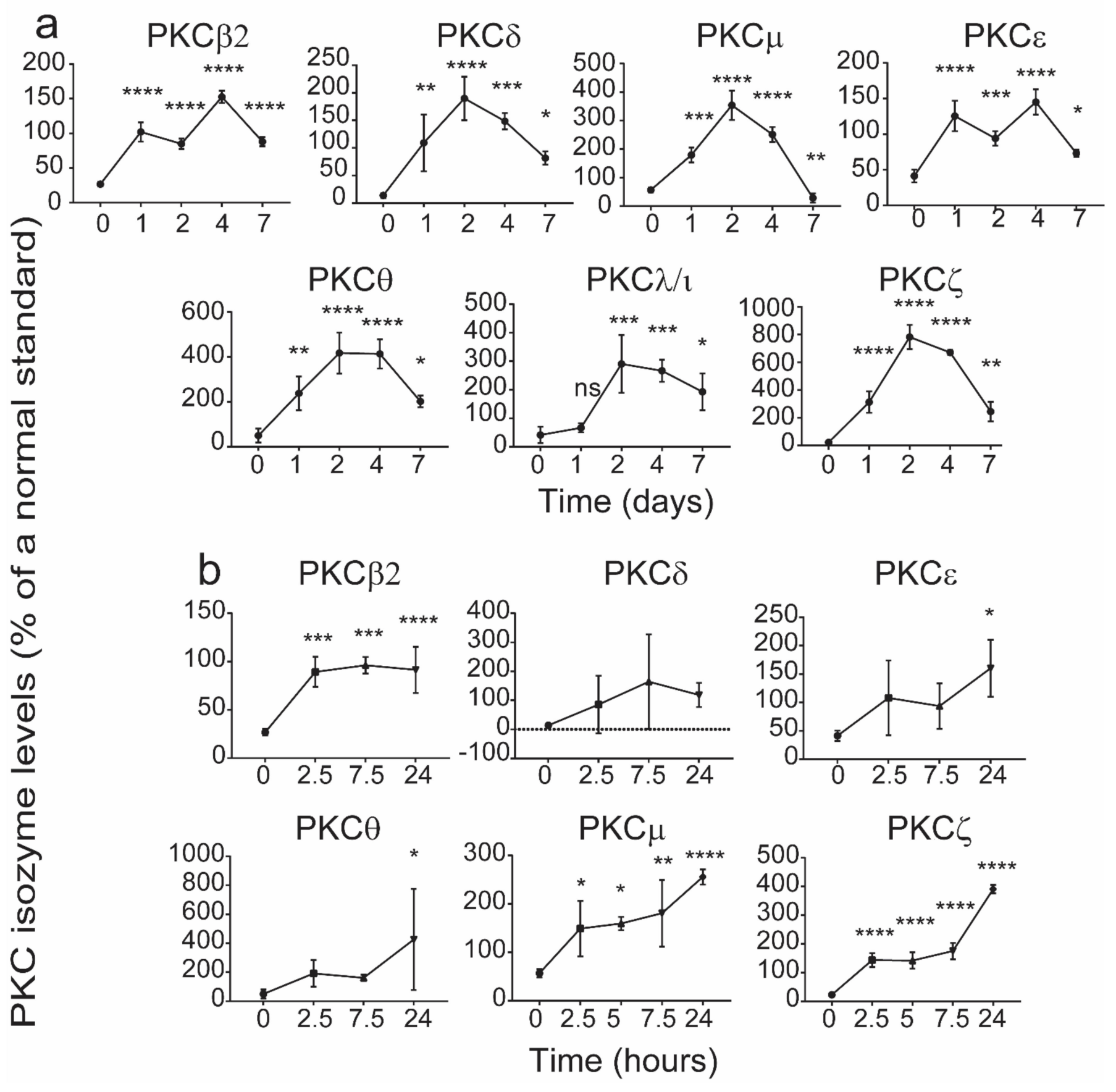

Figure 6. Changes in levels of $\mathrm{CD}^{+}$CBTC PKC during 7-day maturation. CBMCs with low PKC isozyme expressing $\mathrm{CD}^{+} \mathrm{T}$ cells were cultured in the presence of PHA $(2 \mu \mathrm{g} / \mathrm{mL})$ and rhIL-2 $(10 \mathrm{ng} / \mathrm{mL})$ for 7 days. The levels of PKC isozymes were determined during this culture period (a). For those isotypes which achieved significance at 1 day, the levels were re-examined prior to $24 \mathrm{~h}$ culture period (b), by flow cytometry. The MFI for the PKCs is expressed as a \% of the control standard and as mean $\pm \operatorname{SD}\left(n=4\right.$ each with cells from a different individual). ${ }^{*} p<0.05,{ }^{* *} p<0.01,{ }^{* * *} p<0.001$, **** $p<0.0001$ compared to day-0. ns: not significant. One-way ANOVA with post hoc Tukey's multiple comparisons test.

\subsection{Relationship between CBTC PKC Isozyme Levels and Cytokine Production in the Matured Cells}

Previous studies showed that the levels of PKC $\zeta$ at birth were associated with the development of $\mathrm{T}$ cells correlating positively with IFN- $\gamma$ production and negatively with IL-9 [14]. Here we examined whether there is any correlation between the levels of expression of other PKC isozymes in $\mathrm{CB} \mathrm{CD} 3^{+} \mathrm{T}$ cells and cytokines produced following their 
maturation. Purified CBTCs were matured in culture by using anti-CD3/-CD28 antibodies and rhIL-2. On day 7, the matured cells (Figures S2 and S3 show the proportions of naïve and memory markers expression in T cells and T cell subsets at day 7) were then harvested and stimulated with PHA and Phorbol 12-myristate 13-acetate (PMA). The number of cytokine-producing cells were measured by flow cytometry. The matured cells produced IFN- $\gamma$, IL-2, LT- $\alpha$, TNF, IL-4, IL-5, IL-9, IL-10, IL-I3, IL-17, IL-21, IL-22 and TGF- $\beta$ [14] (Figure S4).

Examination of the relationship between the PKC isozyme levels in CBTC and cytokine patterns produced by the matured T cells showed that apart from $\mathrm{PKC} \zeta$ there was essentially no correlation with the other PKC isozymes (Table 1). Analysis revealed that PKC $\zeta$ correlates positively with Th1 cell cytokines IFN- $\gamma$, IL-2 and TNF and negatively with a subset of Th2, Th9 cell type (IL-9) development and IL-10 production in CD3 ${ }^{+}$cells (Table 1). This was observed both as analysis of \% cytokine-positive cells and the MFI. While there was some correlation between PKC $\delta$ and IFN- $\gamma /$ IL-4, both cytokines showed a positive correlation (Table 1).

Assessing these cytokine patterns for correlation with PKC isozyme levels in CB $\mathrm{CD}^{+}$and $\mathrm{CD}^{+} \mathrm{T}$ cells showed a similar correlation to the $\mathrm{CD}^{+} \mathrm{T}$ cells (Supplementary Figures S5 and S6). In some cases, while cytokine correlation was not significant in terms of \% T cells, a correlation was also observed when assessed against the cytokine level (MFI levels).

Table 1. Correlation analysis of PKC isozymes and cytokine production in matured $\mathrm{CD}^{+}$cells \#

\begin{tabular}{|c|c|c|c|c|c|c|c|c|c|c|}
\hline Cytokines & PKC $\alpha$ & РКС $\beta 1$ & РКС $\beta 2$ & PKC & $\mathrm{PKC \varepsilon}$ & PKC $\eta$ & PKC $\theta$ & РКС $\mu$ & PKC $\zeta$ & PKC $\lambda / \iota$ \\
\hline IFN- $\gamma(\%)$ & 0.5604 & 0.1782 & 0.4377 & 0.7085 * & 0.4995 & 0.5377 & 0.1967 & 0.3937 & $0.7019 *$ & 0.0939 \\
\hline IFN- $\gamma(\mathrm{MFI})$ & 0.2106 & 0.1976 & 0.1796 & 0.3579 & 0.3686 & 0.1659 & 0.5463 & -0.0134 & $0.6768^{*}$ & -0.1691 \\
\hline IL-2 (\%) & 0.2204 & 0.3329 & 0.1008 & 0.3092 & 0.2727 & 0.1757 & 0.3761 & -0.0376 & 0.5745 & -0.2421 \\
\hline IL-2 (MFI) & 0.2446 & 0.1459 & 0.2505 & 0.4598 & 0.2192 & 0.2446 & 0.4263 & 0.2310 & 0.7079 * & -0.0340 \\
\hline TNF (\%) & 0.3748 & 0.2478 & 0.2076 & 0.4679 & 0.3332 & 0.2666 & -0.0105 & 0.0986 & 0.5599 & -0.0989 \\
\hline TNF (MFI) & 0.3008 & 0.3182 & 0.1975 & 0.4791 & 0.3996 & 0.2009 & 0.3994 & 0.0351 & $0.7659 * *$ & -0.1134 \\
\hline LT- $\alpha(\%)$ & 0.3346 & 0.0347 & 0.2112 & 0.3929 & 0.3334 & 0.1884 & -0.2018 & 0.1209 & 0.3434 & 0.0537 \\
\hline LT- $\alpha$ (MFI) & -0.0937 & 0.0765 & -0.2068 & -0.0380 & -0.0044 & -0.1691 & -0.2348 & -0.3628 & 0.2329 & -0.4143 \\
\hline IL-4 (\%) & 0.4928 & 0.2634 & 0.2714 & $0.6645^{*}$ & 0.4175 & 0.3514 & -0.0338 & 0.2853 & 0.5840 & 0.0918 \\
\hline IL-4 (MFI) & 0.2515 & 0.2140 & 0.0579 & 0.4423 & 0.1989 & 0.0969 & -0.1759 & 0.0935 & 0.4623 & -0.1301 \\
\hline IL-5 (\%) & 0.2875 & 0.5194 & 0.1459 & 0.0834 & 0.5722 & 0.1974 & 0.4155 & -0.2627 & 0.2405 & 0.0372 \\
\hline IL-5 (MFI) & -0.0224 & 0.1130 & -0.1156 & -0.0436 & 0.3052 & -0.1455 & 0.1579 & -0.3850 & 0.0816 & -0.1837 \\
\hline IL-9 (\%) & -0.4542 & -0.4489 & -0.3473 & $-0.6409 *$ & -0.4878 & -0.3095 & -0.4324 & -0.1984 & $-0.8345^{* *}$ & -0.03258 \\
\hline IL-9 (MFI) & -0.5337 & -0.6502 & -0.4375 & -0.6236 & -0.5397 & -0.4115 & -0.4924 & -0.1557 & $-0.881^{* * *}$ & -0.1508 \\
\hline IL-10 (\%) & -0.2731 & -0.3727 & -0.1408 & -0.4348 & -0.2676 & -0.0802 & -0.0477 & -0.0500 & -0.6230 & 0.1204 \\
\hline IL-10 (MFI) & -0.4495 & -0.3071 & -0.2806 & -0.5754 & -0.4010 & -0.3320 & -0.1614 & -0.2134 & $-0.6725^{*}$ & 0.0095 \\
\hline IL-13 (\%) & -0.1708 & -0.1348 & -0.1926 & -0.1691 & -0.0013 & -0.0055 & 0.4277 & -0.1217 & -0.2527 & -0.1113 \\
\hline IL-13 (MFI) & -0.3522 & -0.3389 & -0.3298 & -0.4816 & -0.3356 & -0.3757 & 0.0836 & -0.2117 & -0.5320 & -0.0616 \\
\hline IL-17 (\%) & -0.083 & -0.5377 & 0.0448 & -0.2234 & -0.0655 & 0.1499 & 0.0774 & 0.1560 & -0.5995 & 0.2036 \\
\hline IL-17 (MFI) & 0.2200 & $0.6979 *$ & 0.1645 & -0.0019 & 0.3411 & 0.0338 & 0.1120 & -0.3631 & 0.4925 & -0.0400 \\
\hline L-21 (\%) & 0.5002 & 0.3347 & 0.2669 & 0.4598 & 0.5308 & 0.3461 & -0.0795 & 0.1010 & 0.5185 & 0.1458 \\
\hline IL-21 (MFI) & 0.0205 & -0.2084 & -0.0434 & 0.04250 & -0.1240 & -0.0438 & -0.3547 & 0.1681 & 0.0046 & -0.0509 \\
\hline IL-22 (\%) & 0.0561 & -0.0125 & 0.0720 & 0.2144 & 0.2900 & 0.08116 & 0.7090 * & -0.03731 & 0.4114 & -0.2888 \\
\hline IL-22 (MFI) & 0.2119 & 0.4719 & -0.0041 & 0.3309 & 0.3908 & 0.04281 & 0.0788 & -0.2496 & 0.4745 & -0.2407 \\
\hline TGF- $\beta(\%)$ & 0.2417 & -0.6425 & 0.3993 & 0.1699 & 0.2979 & 0.5000 & 0.5319 & 0.5087 & -0.291 & 0.3904 \\
\hline TGF- $\beta$ (MFI) & 0.1783 & -0.0354 & 0.2476 & -0.0299 & 0.4619 & 0.1653 & 0.5937 & -0.1791 & 0.3515 & 0.0906 \\
\hline
\end{tabular}

${ }^{\#}$ Data represents Pearson correlation (r). Samples $n=10 .{ }^{*} p<0.05,{ }^{* *} p<0.01,{ }^{* * *} p<0.001$. Correlations were performed using the two-tailed Pearson correlation.

\section{Discussion}

The current data on naïve CBTC PKC isozyme expression show reduced levels of PKC isozymes in $\mathrm{CB} \mathrm{CD3}^{+} \mathrm{T}$ cells compared to levels in peripheral blood $\mathrm{CD}^{+} \mathrm{T}^{+}$cells from adults. The expression levels of $\mathrm{PKC} \beta 2, \delta, \mu, \zeta, \varepsilon, \theta$ and $\lambda / \iota$ isozymes in $\mathrm{CB} \mathrm{CD}^{+}$ $T$ cells were significantly reduced and the data extend the previous findings on reduced levels of PKC isozymes in CBTC, based on Western blot assays [10]. In the main, findings 
showed that the isozyme deficiency between the first [8], second [13] and this study was in agreement. However there was a difference in either $\beta 1$ or $\theta$ expression, perhaps due to the cohorts studied; while the initial studies were from ad hoc deliveries [10], the other involved women with a history of allergic diseases [8] and the present study involved caesarean births. While there was a difference between each of the two published reports $[8,10]$ and this study, with respect to either $\beta 1$ or $\theta$, this could be explained in the cohorts where in initial studies it was not selective [10], but in the other it involved those with a history of allergic diseases [8], and in the present study they were from caesarean births. With low PKC $\zeta$ levels in CBTCs known to be correlated with increased risk of allergy and the maturation of the T cells towards a Th2 bias [14], we examined whether the expression of the other PKC isozymes correlated with the expression of specific cytokines patterns. Only PKC $\zeta$ has a positive association with T cell maturation towards a Th1 cell cytokine bias (e.g., IFN- $\gamma$ ) and a negative association with Th9 (IL-9) cell development, with no associations between the other deficient PKC isozymes and specific cytokine patterns. These findings support previous observations that only CBTC PKC $\zeta$ levels correlated with allergy sensitization and the risk of developing allergy in childhood $[8,9,15]$. Furthermore, knocking down of PKC , expression in CBTC skewed their development towards a Th2 cytokine phenotype [5].

Examination of the $\mathrm{CB} \mathrm{CD} 4^{+}$and $\mathrm{CD} 8^{+} \mathrm{T}$ cells revealed that essentially similar PKC isozymes were deficient in the subpopulations as in the total $\mathrm{T}$ cells with some differences in $\mathrm{PKC} \varepsilon$ and $\theta$ for the $\mathrm{CD}^{+} \mathrm{T}$ cells. Indeed, the PKC isozyme expression between CD4 and CD8 cells was significantly correlated. This suggests that measurements in the total $\mathrm{T}$ cell population as a biomarker are appropriate. While CD8 $\mathrm{T}$ cells are known for their cytotoxic function, e.g., against either virus-infected cells, cancer cells, or both [16], as well as immunosuppressive actions [17], there is increasing evidence suggesting their critical role in allergy development $[18,19]$. Asthmatic patients with reduced number of IFN- $\gamma^{+}$ CD8 $\mathrm{T}$ cells (Tc1) and high frequency of IL- $13^{+}$CD8 T cells (Tc2) was associated with severity of disease [20]. High frequency of IL-9+ CD8 T cells (Tc9) have been associated with eosinophilia and high fractioned exhaled nitric oxide of allergic asthma [21]. Thus, it is not surprising that the associations with PKC $\zeta$ are similar for CD4 and CD8 T cells.

A control on allergy may be achieved by regulating cytokine production, which, based on our previous $[5,8,9,14]$ and present findings, both are linked to the expression of PKC $\zeta$. $\mathrm{CD}^{+}$Th2 cytokines, such as IL-4 (class switch to IgE in B cells), IL-5 (development, survival, activation and differentiation of eosinophils, mast cells and enhanced degranulation of basophils) and IL-13 (class switch to IgE, activation of mast cells, enhanced epithelial cell mucus production and augmented eosinophil trafficking to mucosal sites), are the hallmark of allergic conditions [11,22-24]. IL-9 is produced by Th9 cells which are a subset of Th2 cells expressing peroxisome proliferator-activated receptor gamma [25], which develop in the presence of transforming growth factor-beta (TGF- $\beta$ ) and IL-4 [26-28]; IL-9 plays a role in allergy development [29-33] by increasing IgE expression on B cells [34] and causing bronchial hyperresponsiveness in inhaled methacholine-induced asthma [14,35]. IL-9 also plays a pathogenic role in allergic asthma by controlling mast cells (survival and proliferation, increases expression of proteases and FceRI expression [32,36-38]), epithelial cells (increase mucus production) and promotes airway eosinophilia (eosinophil survival, differentiation and IL-5 Receptor expression [39,40]). The Th1 cytokine, IFN- $\gamma$, inhibits Th2 and Th9 development and survival [22-24,26].

The low expression of PKC isozymes in CBTC appears to be a transient state that may be critical in determining the fate of $\mathrm{T}$ cell maturation following exposure to different environments. However, the 'normalisation' of these isozymes is required to elicit effective immune responses, once matured, irrespective of whether there is a propensity towards a Th1 or Th2/Th9 response. Here we demonstrate that the PKC isozymes that are expressed in deficient amounts in CBTC increase following the addition of the maturation signal, PHA. This occurred rapidly within the first $24 \mathrm{~h}$ of culture suggesting that the window of opportunity to modify these levels for intervention purposes is short. Previously we 
have demonstrated that supplementing women during pregnancy with n-3 polyunsaturated fatty acids (fish oil), results in significant increases in $\mathrm{PKC} \zeta$ levels in CBTC from their babies $[8,15]$. This increase was likely to be epigenetically controlled through the acetylation of histone $\mathrm{H} 3$ in the $P K C Z$ gene promoter region [5]. Given this response to n-3 fatty acid supplementation, it is possible that $\mathrm{PKC} \zeta$ levels could also be altered by using other environmental approaches, provided that these manipulations occurred prenatally or early perinatally. Although the increased prevalence of allergies worldwide is widely recognised, the reason behind this is still unclear. A rather stable population genetic profile could not explain the increased prevalence of atopy and allergy in industrialized countries, but a skewed exposure toward harmful rather than protective epigenetically-driven environmental factors is more plausible [41], which may act at this period of low PKC $\zeta$. This now provides a basis for further exploration of the characteristics of the deficiency in neonates as a prelude to attempt interventions to decrease the risk of allergy development.

As PKC $\zeta$ has been found to be a principal biomarker that can predict allergy development risk [8,9], this enzyme can potentially be targeted to prevent allergy development, by raising its levels in utero [8]. For the first time, the current findings provide evidence of the existence of a time window during the postnatal period when environmental influences could be applied to achieve epigenetic modulation of PKC $\zeta$, such as through a simple low-risk nutritional strategy employing fish oil supplementation. Future studies should be aimed to characterize this transient deficiency in neonates during maturation in vivo.

\section{Materials and Methods}

\subsection{Reagents}

Cell culture reagents used include RPMI 1640 medium supplemented with L-Glutamine (Thermo Fisher Scientific, Waltham, MC, USA, 11875-093), X-VIVO 15 medium (Lonza, BSL, Switzerland, 04418Q) and foetal calf serum (FCS) (Serana, Pessin, German, FBS-AU-015). PHA, PMA and human AB serum were obtained from Sigma Aldrich (St. Louis, MO, USA). The rhIL-2 was purchased from PeproTech (Rocky Hill, NJ, USA). The monoclonal antibodies against PKC isozymes and cytokines are listed in Tables 1-3 with all the relevant details.

Table 2. Staining panel for the determination of PKC isozymes expression.

\begin{tabular}{|c|c|c|}
\hline Antibody (Clone) & Fluorochrome & Cat/Company \\
\hline Anti-PKC $\alpha(\mathrm{H}-7)$ & AF647 & sc-8393/Santa Cruz \\
\hline Anti-PKC $\beta I I(F-7)$ & AF647 & sc-13149/Santa Cruz \\
\hline Anti-PKC $\beta 1$ (EPR18512) & AF647 & ab223452/Abcam \\
\hline Anti-PKC $\zeta(\mathrm{H}-1)$ & PE & sc-17781/Santa Cruz \\
\hline Anti-PKC $\theta(\mathrm{E}-7)$ & PE & sc-1680/Santa Cruz \\
\hline Anti-PKC $\lambda / \iota(\mathrm{H}-12)$ & PE & sc-17837/Santa Cruz \\
\hline Anti-PKCๆ (EPR18513) & AF488 & ab179524/Abcam \\
\hline Anti-PKC $\delta$ (EPR17075) & AF488 & ab206282/Abcam \\
\hline Anti-PKC $\varepsilon$ (EPR1482) & AF488 & ab217980/Abcam \\
\hline Anti-PKC $\mu($ EP1493Y) & AF647 & ab51246/Abcam \\
\hline Mouse IgG1k Isotype control (MOPC-31C) & AF647 & $566011 / \mathrm{BD}$ \\
\hline Rabbit mAb IgG Isotype Control & AF488 & $2975 / \mathrm{CST}$ \\
\hline Rabbit mAb IgG Isotype Control & AF647 & $2985 / \mathrm{CST}$ \\
\hline Mouse mAb IgG2ak (X39) & PE & $340459 / \mathrm{BD}$ \\
\hline Anti-CD3 (SK7) & APC-H7 & $560176 / \mathrm{BD}$ \\
\hline Anti-CD8 (RPA-T8) & PE-Cy7 & $557746 / \mathrm{BD}$ \\
\hline
\end{tabular}

BD—BD Biosciences (Franklin Lakes, NJ, USA), CST—Cell Signaling Technologies (Danvers, MA, USA), Santa Cruz-Santa Cruz Biotechnology (Dallas, TX, USA), Abcam-Abcam (Cambridge, UK). 
Table 3. Antibodies panel\#1 for T cells cytokines.

\begin{tabular}{ccc}
\hline Antibody (Clone) & Fluorochrome & Cat/Company \\
\hline Anti-IL-2 (5344.111) & BV421 & $562914 / \mathrm{BD}$ \\
Anti-IL-10 (JES3-9D7) & AF488 & $501413 /$ BioLegend \\
Anti-LT- $\alpha$ (359-81-11) & PE & $554556 /$ BD \\
Anti-IL-17A (N49-653) & PerCP-Cy 5.5 & $560799 /$ BD \\
Anti-TGF- 3 I (TW4-2F8) & PE/Cy7 & $349610 /$ BioLegend \\
Anti-TNF (MAb11) & APC & $554514 /$ BD \\
Anti-IFN- $\gamma$ (4S.B3) & APC/Cy7 & $502530 /$ BioLegend \\
& BV510 (viability stain) & $564406 /$ BD \\
\hline BD-BD Biosciences (Franklin Lakes, NJ, USA), BioLegend-BioLegend (SD, California, UK).
\end{tabular}

\subsection{Ethics Statement}

Human blood sample collection and all experimental procedures were approved by the Human Research Ethics Committee of the Women's and Children's Health Network (WCHN), Adelaide, South Australia, in accordance with the National Statement on Ethical Conduct in Human Research (2007, updated 2018) (National Health and Medical Research Council Act 1992). Venous blood was collected from adult volunteers who normally donated blood as 'healthy' controls for pathology testing, with their informed consent. The gender of the donors was 15 females and 16 males. Umbilical cord blood (CB) from healthy neonates was obtained with informed consent from pregnant women undergoing elective caesarean section. Gestation age was from 37 to 39 weeks (with 28 of the 35 being 38-39 weeks), and only one of these babies also had a sibling involved. Of the 35 babies, 17 were females and 18 were males.

\subsection{Preparation of Mononuclear Cells (MC) from CB and Peripheral Blood of Adult Donors}

$\mathrm{CB}$ and adult blood in lithium-heparin were applied to Ficoll Paque Plus media (GE Healthcare, Uppsala, Sweden) density gradient centrifugation and the MC which resolved at the interface harvested. The cells were washed in complete medium (RPMI1640 supplemented with L-glutamine $(100 \mathrm{U} / \mathrm{mL})$, penicillin $(100 \mu \mathrm{g} / \mathrm{mL})$, streptomycin $(100 \mu \mathrm{g} / \mathrm{mL})$ and $10 \%$ FCS $)$. The cells were cryopreserved at $5-10 \times 10^{6} / \mathrm{mL}$ in cell freezing media containing FCS $(90 \%)$ and DMSO $(10 \%)$ as previously described [12].

\subsection{Isolation of $T$ Cells}

The $\mathrm{T}$ cells were isolated by negative selection using the EasySep Human $\mathrm{CD}^{+} \mathrm{T}$ cell Isolation Kit (Stemcell Technologies, Vancouver, BC, Canada). The MCs were rapidly thawed and washed in separation buffer (phosphate-buffered saline (PBS) containing 2\% FCS and $1 \mathrm{mM}$ EDTA). Viability assessed by Trypan blue exclusion was approximately $90 \%$. The cells at $5 \times 10^{7}$ cells $/ \mathrm{mL}$ of separation buffer, in polystyrene round-bottom tubes (Corning, AZ, USA, 352058) were incubated with $50 \mu \mathrm{L} / \mathrm{mL}$ of the EasySep Human CD3 ${ }^{+}$ T Cell Isolation Cocktail for $5 \mathrm{~min}$. Furthermore, $50 \mu \mathrm{L} / \mathrm{mL}$ of EasySep Dextran Rapid Spheres was added to cells and the non T cells were removed with an EasySep Magnet (Stemcell Technologies, Vancouver, BC, Canada, 18000). The resultant CBTCs preparation had a purity of $\geq 97 \%$.

\subsection{CBTC Maturation}

CBTCs were matured using an established model. The cells were cultured in the presence of anti-CD3 and anti-CD28 antibodies [14]. Briefly, $2.5 \mu \mathrm{g} / \mathrm{mL}$ anti-CD3 antibodies (OKT3, Abcam, Cambridge, UK) were immobilised in 24 well plates in Hank's balanced salt solution (HBSS). The plates were refrigerated overnight or incubated for $3 \mathrm{~h}$ at $37^{\circ} \mathrm{C}$, and then washed with HBSS. At the initiation of the culture, to $1 \times 10^{6} \mathrm{CBTC}$ was added $1 \mu \mathrm{g} / \mathrm{mL}$ anti-CD28 antibodies (Clone CD28.2, eBiosciences, San Diego, CA, USA) in a total volume of $1 \mathrm{~mL}$. In some assays, CBMC at $1 \times 10^{6}$ cells $/ \mathrm{mL}$ in complete media were matured by using PHA ( $2 \mu \mathrm{g} / \mathrm{mL}$, final concentration). On the 3rd day, the cells 
were counted and reseeded at $1 \times 10^{6} / \mathrm{mL}$ with rhIL-2 $(10 \mathrm{ng} / \mathrm{mL})$. This was repeated on day 5. The expression of CD45RA/RO surface expression was measured on day 7 by flow cytometry. The cells were used for cytokine production studies as required.

\subsection{Flow Cytometric Detection of PKC Isozymes}

The expression of PKC isozymes was assessed as described previously [12]. Briefly, either whole blood or $2 \times 10^{5}$ CBMCs were incubated with anti-CD3 APC-H7 and antiCD8 PE-Cy7, both from BD Biosciences (Franklin Lakes, NJ, USA) for surface staining for 15-20 min. The cells were then fixed with BD Cytofix/Cytoperm (BD, 555028) and permeabilized with NET-Gel. Furthermore, $1 \mu \mathrm{g}$ of mouse/rabbit IgG Fc blocking reagent was added for $10 \mathrm{~min}$. The optimal amount of fluorochrome-conjugated anti-PKC isozymes antibodies or isotype controls (Table 2) were added as appropriate. After $30 \mathrm{~min}$ of incubation at room temperature (RT) in the dark, the cells were washed twice. They were then analysed on a FACSCanto II (BD Biosciences, NJ, USA).

\subsection{Measurement of Intracellular Cytokines}

The assays were conducted essentially as previously described using BD Cytofix/ Cytoperm Plus Permeabilization Kit with GolgiPlug [14]. Briefly, the T cells at $1 \times 10^{6} / \mathrm{mL}$ in RPMI-1640/2.5\% AB serum were stimulated with PMA $(50 \mathrm{nM})$ and PHA $(2 \mu \mathrm{g} / \mathrm{mL})$ in the presence of Brefeldin A (GolgiPlug) and incubated at $37^{\circ} \mathrm{C} / 5 \% \mathrm{CO}_{2}$ for $16-20 \mathrm{~h}$. Cells were washed and incubated with BD Horizon Fixable Viability Stain 510 (FVS510) stock solution (1:1000) in protein- and sodium azide-free PBS for $15 \mathrm{~min}$. After washing, cells were treated with anti-CD45 APC-H7 (2D1) and anti-CD3 PE-Cy5 (HIT3a) and incubated at RT in the dark for 15-20 min. The cells were fixed with BD Cytofix/CytoPerm solution for $20 \mathrm{~min}$ and permeabilized with BD Perm/Wash solution for $10 \mathrm{~min}$ at RT in the dark. For detection of intracellular cytokine, cells were treated with fluorochrome-conjugated antibodies (see Tables 3 and 4) and then incubated for $30 \mathrm{~min}$ at RT in the dark. After the incubation, cells were washed twice with BD Perm/Wash; the samples were analysed on a FACSCanto II. Data analysis was performed using FlowJo v10.1 for cytokine expressing $T$ cells. Cells were analysed after the exclusion of doublets and dead cells by gating on the FVS510 ${ }^{-}$cell population.

Table 4. Antibodies panel\#2 for T cells cytokines.

\begin{tabular}{ccc}
\hline Antibody (Clone) & Fluorochrome & Cat/Company \\
\hline Anti-IL-13 (JES10-5A2) & BV421 & $563580 / \mathrm{BD}$ \\
Anti-IL-4 (MP4-25D2) & FITC & $562047 / \mathrm{BD}$ \\
Anti-IL-21 (3A3-N2.1) & PE & $562042 / \mathrm{BD}$ \\
Anti-IL-9 (MH9A3) & PerCP-Cy 5.5 & $561461 / \mathrm{BD}$ \\
Anti-IL-5 (TRFK5) & APC & $562048 / \mathrm{BD}$ \\
Anti-IL-22 (2G12A41) & PE/Cy7 & $366707 /$ BioLegend \\
Anti-IFN- $\gamma$ (4S.B3) & APC/Cy7 & $502530 /$ BioLegend \\
& BV510 (viability stain) & $564406 / \mathrm{BD}$ \\
\hline
\end{tabular}

BD—BD Biosciences (Franklin Lakes, NJ, USA), BioLegend—BioLegend (SD, California, UK).

\subsection{Statistical Analysis}

Statistical analyses were conducted by one-way ANOVA followed by post hoc Tukey's multiple comparisons test, or Student's $t$-test. The two-tailed Pearson correlation coefficient was used for examining data for the presence of correlation. These were performed using GraphPad Prism v9 (GraphPad Software, La Jolla, CA, USA). A $p$ value of $<0.05$ was considered significant.

Supplementary Materials: The following are available online at https:/ / www.mdpi.com/article/10 $.3390 /$ ijms222312650/s1. 
Author Contributions: Conceptualization, K.P., A.F., C.S.H. and S.L.P.; validation, K.P., A.Q. and A.F.; formal analysis, K.P.; investigations, K.P. and A.F.; data curation, K.P., A.F. and A.Q.; writingoriginal draft preparation, K.P. and A.F.; writing—critical review and editing, A.F., K.P., C.S.H., A.Q., M.J.S., S.L.P. and S.C.B.; supervision, A.F., C.S.H. and A.Q.; funding acquisition, A.F., S.L.P. and C.S.H. All authors have read and agreed to the published version of the manuscript.

Funding: This research was funded by the Women's and Children's Hospital Research Foundation, South Australia, and the National Health and Medical Research Council of Australia.

Institutional Review Board Statement: The procurement of human blood and all experimental procedures were approved by the Human Research Ethics Committee of the Women's and Children's Health Network (WCHN), Adelaide, South Australia, the Southern Adelaide Clinical Human Research Ethics Committee in accordance to the National Statement on Ethical Conduct in Human Research (2007, updated 2018; National Health and Medical Research Council Act 1992).

Informed Consent Statement: Informed consent was obtained from all subjects involved in the study.

Data Availability Statement: The datasets generated during and analysed during the current study are available from the corresponding author on reasonable request.

Acknowledgments: We are grateful to Andrew McPhee and Annabelle Small for assistance with procuring the cord blood samples and to staff from the Immunopathology Department, SA Pathology, Women's and children's Hospital for assistance with adult blood collection.

Conflicts of Interest: The authors declare no conflict of interest.

\section{References}

1. Ono, Y.; Fujii, T.; Ogita, K.; Kikkawa, U.; Igarashi, K.; Nishizuka, Y. The structure, expression, and properties of additional members of the protein kinase C family. J. Biol. Chem. 1988, 263, 6927-6932. [CrossRef]

2. Ono, Y.; Fujii, T.; Igarashi, K.; Kuno, T.; Tanaka, C.; Kikkawa, U.; Nishizuka, Y. Phorbol ester binding to protein kinase C requires a cysteine-rich zinc-finger-like sequence. Proc. Natl. Acad. Sci. USA 1989, 86, 4868-4871. [CrossRef] [PubMed]

3. Reina-Campos, M.; Diaz-Meco, M.T.; Moscat, J. The Dual Roles of the Atypical Protein Kinase Cs in Cancer. Cancer Cell 2019, 36, 218-235. [CrossRef] [PubMed]

4. Duran, A.; Diaz-Meco, M.T.; Moscat, J. Essential role of RelA Ser311 phosphorylation by zetaPKC in NF-kappaB transcriptional activation. EMBO J. 2003, 22, 3910-3918. [CrossRef]

5. Harb, H.; Irvine, J.; Amarasekera, M.; Hii, C.S.; Kesper, D.A.; Ma, Y.; Ferrante, A. The role of PKC $\zeta$ in cord blood T-cell maturation towards Th1 cytokine profile and its epigenetic regulation by fish oil. Biosci. Rep. 2017, 37, BSR20160485. [CrossRef]

6. Martin, P.; Moscat, J. Th1/Th2 Differentiation and B Cell Function by the Atypical PKCs and Their Regulators. Front. Immunol. 2012, 3, 241. [CrossRef]

7. Metz, P.J.; Arsenio, J.; Kakaradov, B.; Kim, S.H.; Remedios, K.A.; Oakley, K.; Chang, J.T. Regulation of Asymmetric Division and CD8 ${ }^{+} \mathrm{T}$ Lymphocyte Fate Specification by Protein Kinase C $\zeta$ and Protein Kinase C $\lambda /$ ı. J. Immunol. 2015, 194, 2249-2259. [CrossRef]

8. Prescott, S.L.; Irvine, J.; Dunstan, J.A.; Hii, C.; Ferrante, A. Protein kinase C zeta: A novel protective neonatal T-cell marker that can be upregulated by allergy prevention strategies. J. Allergy Clin. Immunol. 2007, 120, 200-206. [CrossRef]

9. D’Vaz, N.; Ma, Y.; Dunstan, J.A.; Lee-Pullen, T.F.; Hii, C.; Meldrum, S.; Prescott, S.L. Neonatal protein kinase C zeta expression determines the neonatal T-Cell cytokine phenotype and predicts the development and severity of infant allergic disease. Allergy 2012, 67, 1511-1518. [CrossRef]

10. Hii, C.S.; Costabile, M.; Mayne, G.C.; Der, C.J.; Murray, A.W.; Ferrante, A. Selective deficiency in protein kinase C isoenzyme expression and inadequacy in mitogen-activated protein kinase activation in cord blood T cells. Biochem. J. 2003, 370 Pt 2, 497-503. [CrossRef]

11. Acevedo, N.; Alashkar Alhamwe, B.; Caraballo, L.; Ding, M.; Ferrante, A.; Garn, H.; van Esch, B.C. Perinatal and Early-Life Nutrition, Epigenetics, and Allergy. Nutrients 2021, 13, 724. [CrossRef]

12. Perveen, K.; Quach, A.; McPhee, A.; Prescott, S.L.; Barry, S.C.; Hii, C.S.; Ferrante, A. Validation of monoclonal anti-PKC isozyme antibodies for flow cytometry analyses in human T cell subsets and expression in cord blood T cells. Sci. Rep. 2019, 9, 9263. [CrossRef]

13. Prescott, S.L.; Macaubas, C.; Smallacombe, T.; Holt, B.J.; Sly, P.D.; Loh, R.; Holt, P.G. Reciprocal age-related patterns of allergenspecific T-cell immunity in normal vs. atopic infants. Clin. Exp. Allergy 1998, 28 (Suppl. 5), 39-44, discussion 50-1. [CrossRef]

14. Perveen, K.; Quach, A.; McPhee, A.; Prescott, S.L.; Barry, S.C.; Hii, C.S.; Ferrante, A. Cord Blood T Cells Expressing High and Low PKC $\zeta$ Levels Develop into Cells with a Propensity to Display Th1 and Th9 Cytokine Profiles, Respectively. Int. J. Mol. Sci. 2021, 22, 4907. [CrossRef]

15. Ferrante, A.; Prescott, S. Immunological Immaturity of the Neonate, Protein Kinase C Zeta and Allergy. J. Neonatal Biol. 2014, 3 , 106e. [CrossRef] 
16. Durgeau, A.; Virk, Y.; Corgnac, S.; Mami-Chouaib, F. Recent Advances in Targeting CD8 T-Cell Immunity for More Effective Cancer Immunotherapy. Front. Immunol. 2018, 9, 14. [CrossRef]

17. Yu, Y.; Ma, X.; Gong, R.; Zhu, J.; Wei, L.; Yao, J. Recent advances in CD8 ${ }^{+}$regulatory T cell research. Oncol. Lett. 2018, 15, 8187-8194. [CrossRef]

18. Hinks, T.S.C.; Hoyle, R.D.; Gelfand, E.W. CD8 ${ }^{+}$Tc2 cells: Underappreciated contributors to severe asthma. Eur. Respir. Rev. 2019, 28, 190092. [CrossRef]

19. Yu, W.; Zhou, X.; Dunham, D.; Lyu, S.C.; Manohar, M.; Zhang, W.; Nadeau, K. Allergen-specific CD8 ${ }^{+}$T cells in peanut-allergic individuals. J. Allergy Clin. Immunol. 2019, 143, 1948-1952. [CrossRef]

20. Hinks, T.S.C.; Zhou, X.; Staples, K.J.; Dimitrov, B.D.; Manta, A.; Petrossian, T.; Djukanović, R. Innate and adaptive T cells in asthmatic patients: Relationship to severity and disease mechanisms. J. Allergy Clin. Immunol. 2015, 136, 323-333. [CrossRef]

21. Wang, W.; Cheng, Z.S.; Chen, Y.F.; Lin, Y.H. Increased circulating IL-9-producing CD8 ${ }^{+} \mathrm{T}$ cells are associated with eosinophilia and high FeNO in allergic asthmatics. Exp. Ther. Med. 2016, 12, 4055-4060. [CrossRef] [PubMed]

22. Stone, K.D.; Prussin, C.; Metcalfe, D.D. IgE, mast cells, basophils, and eosinophils. J. Allergy Clin. Immunol. 2010, 125 (Suppl. 2), S73-S80. [CrossRef] [PubMed]

23. Gour, N.; Wills-Karp, M. IL-4 and IL-13 signaling in allergic airway disease. Cytokine 2015, 75, 68-78. [CrossRef] [PubMed]

24. Kumar, R.K.; Herbert, C.; Yang, M.; Koskinen, A.M.; McKenzie, A.N.; Foster, P.S. Role of interleukin-13 in eosinophil accumulation and airway remodelling in a mouse model of chronic asthma. Clin. Exp. Allergy 2002, 32, 1104-1111. [CrossRef] [PubMed]

25. Micossé, C.; von Meyenn, L.; Steck, O.; Kipfer, E.; Adam, C.; Simillion, C.; Schlapbach, C. Human "TH9" cells are a subpopulation of PPAR- $\gamma^{+}$TH2 cells. Sci. Immunol. 2019, 4, eaat5943. [CrossRef]

26. Schmitt, E.; Germann, T.; Goedert, S.; Hoehn, P.; Huels, C.; Koelsch, S.; Rüde, E. IL-9 production of naive CD4 ${ }^{+}$T cells depends on IL-2, is synergistically enhanced by a combination of TGF-beta and IL-4, and is inhibited by IFN-gamma. J. Immunol. 1994, 153, 3989-3996.

27. Dardalhon, V.; Awasthi, A.; Kwon, H.; Galileos, G.; Gao, W.; Sobel, R.A.; Kuchroo, V.K. IL-4 inhibits TGF-beta-induced Foxp3 ${ }^{+}$T cells and, together with TGF-beta, generates IL-9 IL-10 $^{+}$Foxp3 ${ }^{-}$effector T cells. Nat. Immunol. 2008, 9, 1347-1355. [CrossRef]

28. Veldhoen, M.; Uyttenhove, C.; van Snick, J.; Helmby, H.; Westendorf, A.; Buer, J.; Stockinger, B. Transforming growth factor-beta 'reprograms' the differentiation of T helper 2 cells and promotes an interleukin 9-producing subset. Nat. Immunol. 2008, 9, 1341-1346. [CrossRef]

29. Goswami, R.; Kaplan, M.H. A Brief History of IL-9. J. Immunol. 2011, 186, 3283-3288. [CrossRef]

30. Renauld, J.-C. New insights into the role of cytokines in asthma. J. Clin. Pathol. 2001, 54, 577-589. [CrossRef]

31. Hauber, H.P.; Bergeron, C.; Hamid, Q. IL-9 in allergic inflammation. Int. Arch. Allergy Immunol. 2004, 134, 79-87. [CrossRef]

32. Soussi-Gounni, A.; Kontolemos, M.; Hamid, Q. Role of IL-9 in the pathophysiology of allergic diseases. J. Allergy Clin. Immunol. 2001, 107, 575-582. [CrossRef]

33. Liu, G.; Qian, L.; Xu, T.; Yu, J.; Li, M.; Cui, Y. Changes in the Th9 cell population and related cytokines in the peripheral blood of infants with recurrent wheezing. Cent. Eur. J. Immunol. 2020, 45, 60-68. [CrossRef]

34. Petit-Frere, C.; Dugas, B.; Braquet, P.; Mencia-Huerta, J. Interleukin-9 potentiates the interleukin-4-induced IgE and IgG1 release from murine B lymphocytes. Immunology 1993, 79, 146.

35. Temann, U.-A.; Geba, G.P.; Rankin, J.A.; Flavell, R.A. Expression of Interleukin 9 in the Lungs of Transgenic Mice Causes Airway Inflammation, Mast Cell Hyperplasia, and Bronchial Hyperresponsiveness. J. Exp. Med. 1998, 188, 1307-1320. [CrossRef]

36. Matsuzawa, S.; Sakashita, K.; Kinoshita, T.; Ito, S.; Yamashita, T.; Koike, K. IL-9 enhances the growth of human mast cell progenitors under stimulation with stem cell factor. J. Immunol. 2003, 170, 3461-3467. [CrossRef]

37. Sehra, S.; Yao, W.; Nguyen, E.T.; Glosson-Byers, N.L.; Akhtar, N.; Zhou, B.; Kaplan, M.H. TH9 cells are required for tissue mast cell accumulation during allergic inflammation. J. Allergy Clin. Immunol. 2015, 136, 433-440.e1. [CrossRef]

38. Louahed, J.; Kermouni, A.; Van Snick, J.; Renauld, J.-C. IL-9 induces expression of granzymes and high-affinity IgE receptor in murine T helper clones. J. Immunol. 1995, 154, 5061-5070.

39. Gounni, A.S.; Gregory, B.; Nutku, E.; Aris, F.; Latifa, K.; Minshall, E.; Hamid, Q. Interleukin-9 enhances interleukin-5 receptor expression, differentiation, and survival of human eosinophils. Blood J. Am. Soc. Hematol. 2000, 96, $2163-2171$.

40. Dong, Q.; Louahed, J.; Vink, A.; Sullivan, C.D.; Messler, C.J.; Zhou, Y.; Nicolaides, N.C. IL-9 induces chemokine expression in lung epithelial cells and baseline airway eosinophilia in transgenic mice. Eur. J. Immunol. 1999, 29, 2130-2139. [CrossRef]

41. Alaskhar Alhamwe, B.; Khalaila, R.; Wolf, J.; von Bülow, V.; Harb, H.; Alhamdan, F.; Potaczek, D.P. Histone modifications and their role in epigenetics of atopy and allergic diseases. Allergy Asthma Clin. Immunol. 2018, 14, 39. [CrossRef] [PubMed] 